\title{
Short-distance dispersal of black coral larvae: inference from spatial analysis of colony genotypes
}

\author{
K. J. Miller* \\ National Institute of Water and Atmosphere Ltd, PO 14-901, Kilbirnie, Wellington, New Zealand
}

\begin{abstract}
Antipathes fiordensis is a black coral species endemic to the south-western region of New Zealand. Restricted larval dispersal has been demonstrated to occur in A. fiordensis, although the exact scale of larval dispersal is unknown. This study examines the fine-scale $(<50 \mathrm{~m})$ pattern of relatedness between black coral colonies at 3 sites in Doubtful Sound. Fiordland, to infer dispersal distance and gain a better understanding of patch size in this species. At each of the 3 sites the position of all black coral colonies was mapped and allozyme electrophoresis was used to determine the 10-locus genotype of each colony. Two statistical methods were used to examine the association between colony genotype and distance at each of the 3 plots; spatial autocorrelation of individual loci and Mantel's Test which examines the relationship between multi-locus genotypes. At 1 of the 3 sites (Tricky Cove) there was a significant positive association among colonies separated by $<5 \mathrm{~m}$ for 4 of the 6 loci tested. Similarly, Mantel's Test showed a significant positive correlation between genetic distance and Euclidean distance at the Tricky Cove site $(r=0.2, p=0.007)$. These results suggest dispersal of black coral larvae is highly philopatric and that larvae settle very close to parent colonies. However at the other 2 sites there was no spatial association detected among genotypes, indicating either that gametes or larvae are more widely dispersed at these 2 sites $(>50 \mathrm{~m}$ ) or that other ecological and evolutionary factors are operating that have influenced the observed genetic structure of the populations. Genetic studies suggest that gene flow in $A$. fiordensis populations will be restricted and that patch size in this species may be relatively small. These findings will have important implications for the conservation and management of the rare and unique shallow water populations of black corals in New Zealand's fiords.
\end{abstract}

KEY WORDS: Black coral · Larval dispersal · Philopatry

\section{INTRODUCTION}

The role of widespread larval dispersal for the maintenance of genetic heterogeneity in benthic marine species is well recognised (e.g. Hedgecock 1986 , Scheltema 1986). However, philopatry (a mode of dispersal whereby larvae remain at or very near their point of origin) has been described in many sessile marine species (e.g. Olson 1985, Keough \& Chernoff 1987, Ayre \& Dufty 1994). The recruitment of offspring into parental habitats may increase inbreeding, which will lead to loss in heterozygosity and a decrease in

•E-mail:k.miller@niwa.cri.nz overall population fitness (Mitton 1993). Similarly, philopatry will decrease the effective size of local populations relative to their perceived size, which may increase the potential for divergence of local populations through selection and/or genetic drift (e.g. Bertness \& Gaines 1993).

Existing knowledge of the larval biology of New Zealand's endemic black coral Antipathes fiordensis (Grange 1990) suggests larval dispersal will be restricted in this species. The sexually produced planula larvae of $A$. fiordensis are lecithotrophic, negatively buoyant and poor swimmers which crawl on the substrate and may survive for only $10 \mathrm{~d}$ (Miller 1996). These factors, combined with the weak estuarine circulation in the fiord habitat (Stanton \& Pickard 1981), sug- 
gest the larvae of A. fiordensis may have limited dispersal potential. Indeed significant genetic differentiation has been documented among Fiordland black coral populations which are separated by distances of 10 to $15 \mathrm{~km}\left[F_{S T}\right.$ (standardised genetic differentiation among populations) $=0.046, \mathrm{p}<0.001 ; N_{\mathrm{e}} m$ (estimated number of migrants per generation) $=3.2$ to 5.2 ; Miller 1997 $\mathrm{b}$, indicating limited larval dispersal in A. fiordensis.

Many aspects of the behaviour of Antipathes fiordensis larvae are still to be determined. However, direct observations of the limited movement of the crawling sexual planulae of $A$. fiordensis (author's unpubl, data) suggest that dispersal of these larvae may be considerably less than the sampling scale used in earlier genetic studies (i.e. 10 to $15 \mathrm{~km}$; Miller 1997 , Miller \& Grange in press). To gain a realistic estimate of larval dispersal, studies will need to be conducted at much smaller scales than those previously used. For example, the crawling larvae of the solitary coral Balanophyllia elegans settle only $40 \mathrm{~cm}$ from parent colonies (Gerodette 1981), and the demersal larvae of the soft coral Alcyonium siderium settle within metres of their parents (Sebens 1983). If larval dispersal in black corals is restricted similarly, then population subdivision may occur over very small distances (e.g. Hellberg 1994, 1995) and this will not have been apparent in previous analyses.

Spatial autocorrelation is a method designed to determine the dependence of a variable on the value of the same variable at a different location (Cliff \& Ord 1973, Sokal \& Oden 1978a, b), and is particularly useful for detecting and quantifying the scale of genetic subdivision in a population. Autocorrelation has been used successfully to address relationships between neighbouring plants as well as the scale of seed dispersal in plant species (e.g. Dewey \& Heywood 1988, Epperson \& Allard 1989, Peakall \& Beattie 1995). However, to my knowledge it has only been applied in 2 studies of larval dispersal of marine invertebrates (Stoddart 1988, McFadden \& Aydin 1996). Autocorrelation has advantages over other methods of spatial genetic analysis as it can be based on individual genotypes, rather than mean values at site [e.g. $F_{\mathrm{ST}}, G_{\mathrm{ST}}$ (Nei's coefficient of gene differentiation)]. Furthermore, autocorrelation analysis allows detection of spatial patterns at scales smaller than the subdivision or site size, which is particularly useful in populations which are perceived as continuous (Heywood 1991) such as the rock wall populations of Antipathes fiordensis in Fiordland.

In this study I examine the fine-scale genetic relationships among Antipathes fiordensis colonies in order to determine the scale of dispersal of sexually produced black coral planulae and to examine the effects of philopatric dispersal on the population genetic structure of the black corals. Specifically, I have used spatial autocorrelation analyses to examine the relationship between the genotypes of neighbouring black coral colonies to determine whether larvae of A. fiordensis settle within a few metres of parent colonies (as hypothesised for a species with benthic crawling larvae) or whether they are dispersed over greater distances.

\section{MATERIALS AND METHODS}

Field collections. The black coral Antipathes fiordensis is found throughout New Zealand's southern fiords, a marine environment exhibiting a unique combination of physical and biological features, including reduced light levels and restricted water movement, which allow many deep water species to exist in shallow water (Grange et al. 1981). Most of the black coral biomass occurs on vertical rack walls in the fiords, in a continuous, yet patchy 'zone' between depths of 10 and $35 \mathrm{~m}$ (Grange 1985, Grange \& Singleton 1988). The geological composition of the Fiordland region is a mixture of high to medium grade metamorphic rock, primarily gneiss and schist (Suggate et al. 1978).

For this study, black coral colonies were sampled from rock-wall habitats at 3 sites in Doubtful Sound, Fiordland (Fig 1). These 3 sites were separated by approximately 10 to $15 \mathrm{~km}$. At each site an area approximately $300 \mathrm{~m}^{2}$ was marked out and all coral colonies within the plot were tagged and their positions mapped according to an $x-y$ grid system. The ' $x$ ' co-ordinate was measured horizontally from a line suspended vertically through the middle of the plot. The ' $y$ ' coordinate was recorded as depth (to the nearest $10 \mathrm{~cm}$ ) and values were adjusted to compensate for tidal variation at the time of sampling.

To estimate the population structure at each site, the approximate height (in $\mathrm{mm}$ ) of all tagged colonies was recorded. Colony height provides a reasonable estimate of colony age in antipatharians (Grange 1985); hence the colonies were grouped into 4 size categories representing different demographic groups as outlined below. Group I comprised colonies $<150 \mathrm{~mm}$, representing 'recent' recruits less than $10 \mathrm{yr}$ of age based on growth rates of $16 \mathrm{~mm} \mathrm{yr}^{-1}$ (Grange \& Goldberg 1993). Recruitment to black coral populations occurs sporadically and at very low frequencies and colonies $<10 \mathrm{yr}$ suffer very high mortality rates (Grange in press). The probability that this size class will survive to maturity is extremely low. Group II comprised colonies 150 to $300 \mathrm{~mm}$ tall, representing immature colonies between approximately 10 and 20 yr of age which suffer lower mortality rates than Group I (Grange in press). Group 


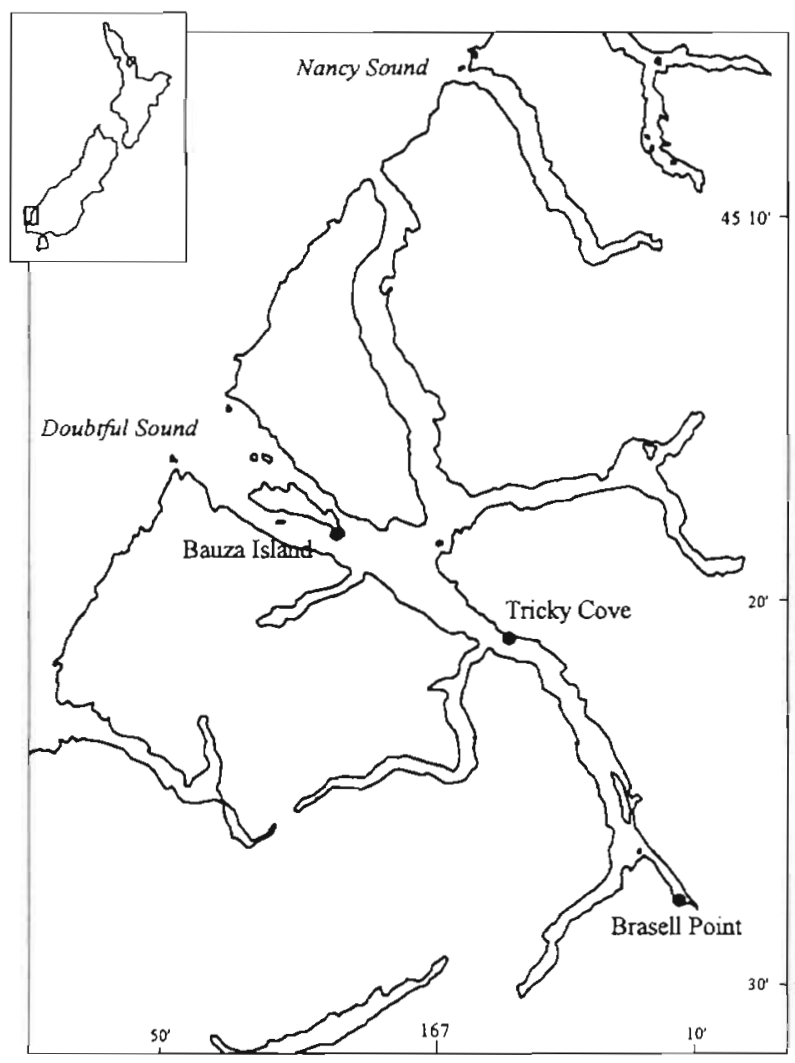

Fig. 1. Map of Doubtful Sound, southwestern New Zealand, indicating the approximate location of the 3 sampling sites

III are corals 300 to $500 \mathrm{~mm}$ tall, representing colonies $>20 \mathrm{yr}$ of age which have very high survivorship (Grange in press) and are at the onset of reproduction (Parker 1995). Finally, Group IV are colonies $>500 \mathrm{~mm}$ representing the stable population of mature adults and includes colonies which may be hundreds of years old (Parker 1995, Grange in press).

Electrophoresis. A small branch tip was removed from all colonies within the spatial plots for genetic analysis. These coral samples were screened for 7 electrophoretic allozymes in order to determine the 10 locus genotypes of all colonies. The choice of the 10 polymorphic loci (Est-1, Est-2, Gpi, Hk-1, Hk-2, Idh, Mdh, Pgm, La-1 and La-2) was based on results from earlier electrophoretic surveys of black corals, and details of running conditions and staining methods can be found in Miller \& Grange (in press).

Genetic analysis. Three different methods were used to examine levels of population structuring at each of the 3 sites. Evidence for genotypic linkage disequilibrium was tested at each site using GENEPOP 1.2 (Raymond \& Rousset 1994) to determine if the 10 loci behave independently. Departures from random mating, as expected under conditions of Hardy-Weinberg equilibrium, were tested using exact tests with rare alleles pooled (Elston \& Forthofer 1977). For these tests, the probability of significance was corrected for multiple simuitaneous tests according to Miller (1966). Wright's fixation index ( $f$ ) was used to determine if departures from random mating were associated with either excesses or deficits of heterozygotes

Genotypic diversity measures for each of the 3 populations were calculated according to Stoddart \& Taylor (1988). The ratio of observed to expected genotypic diversity $\left(G_{O}: G_{E}\right)$ was used to estimate the relative contribution of sexual and asexual reproduction to recruitment at each site. The departure of observed genotypic diversity $\left(G_{0}\right)$ from the genotypic diversity expected under conditions of panmixia $\left(G_{\mathrm{E}}\right)$ was calculated using unpaired $t$-tests (Stoddart \& Tayior 1988).

Spatial analysis. In a system of limited dispersal, where larvae settle close to the parent colonies, a positive correlation between genotypes of colonies separated by small distances would be expected, with a negative or no correlation with increasing distance between colonies (Sokal \& Oden 1978a, b). I used spatial autocorrelation to determine if there was any relationship between colony genotypes and the position of black coral colonies within each plot that might indicate the scale of larval dispersal in Antipathes fiordensis. The autocorrelation coefficient, Moran's $I$, was calculated for 3 distance classes $(0-5 \mathrm{~m}, 5-10 \mathrm{~m}$ and $10-50 \mathrm{~m}$ ) at each site, based on individual allele frequencies (coded as either 1, 0 or 0.5 ) at each locus. Only loci which were polymorphic at 2 or more sites were tested and for each of these calculations were performed for $(n-1)$ alleles. Moran's I typically varies from +1 to -1 , with values close to zero indicating no autocorrelation (i.e. random distribution of genotypes with distance). Negative or positive values of Moran's $I$ indicate negative or positive correlation of genotype with distance respectively. Tests for significant autocorrelation were carried out by comparing the observed and expected values of $I$ under the assumption of no spatial structure.

The analyses described above only test spatial autocorrelation for individual loci. However, a composite of single-locus statistics may not be representative of how the complete genotype behaves. Consequently a multivariate test for spatial association in Antipathes fiordensis was done by comparing the association between multilocus genotypes and spatial distribution within the 3 spatial plots. Mantel's Test, which computes the relationship between 2 distances matrices (Fortin \& Gurevitch 1993), was used. For each of the 3 study sites, matrices of Nei's unbiased genetic distance $(D)$ calculated between colonies, and Euclidean distance between colonies (calculated using $x-y$ coordinates from each plot) were compared. The statistical significance of the association between matrices was 
tested using a permutational test, with the probability of significance calculated by 1000 random permutations (Fortin \& Gurevitch 1993).

\section{RESULTS}

A total of 154 black coral colonies was collected from the 3 sites: 60 at Brasell Point, 29 at Tricky Cove and 65 at Bauza Island. Plots showing the location of colonies within each of the 3 sites are presented in Fig. 2.

The size-frequency distribution of coral colonies varied among sites (Fig. 3), with differences in the population structure indicating differential demographic histories at the 3 sites. Brasell Point was dominated by large, mature colonies ( $>20$ yr old) with relatively few small or immature colonies present in the plot (Fig. 3). In contrast, large mature colonies and 'recent' recruits were common at Tricky Cove with the 2 middle size classes less abundant. Colonies of all 4 size classes were equally represented at Bauza Island (Fig. 3).

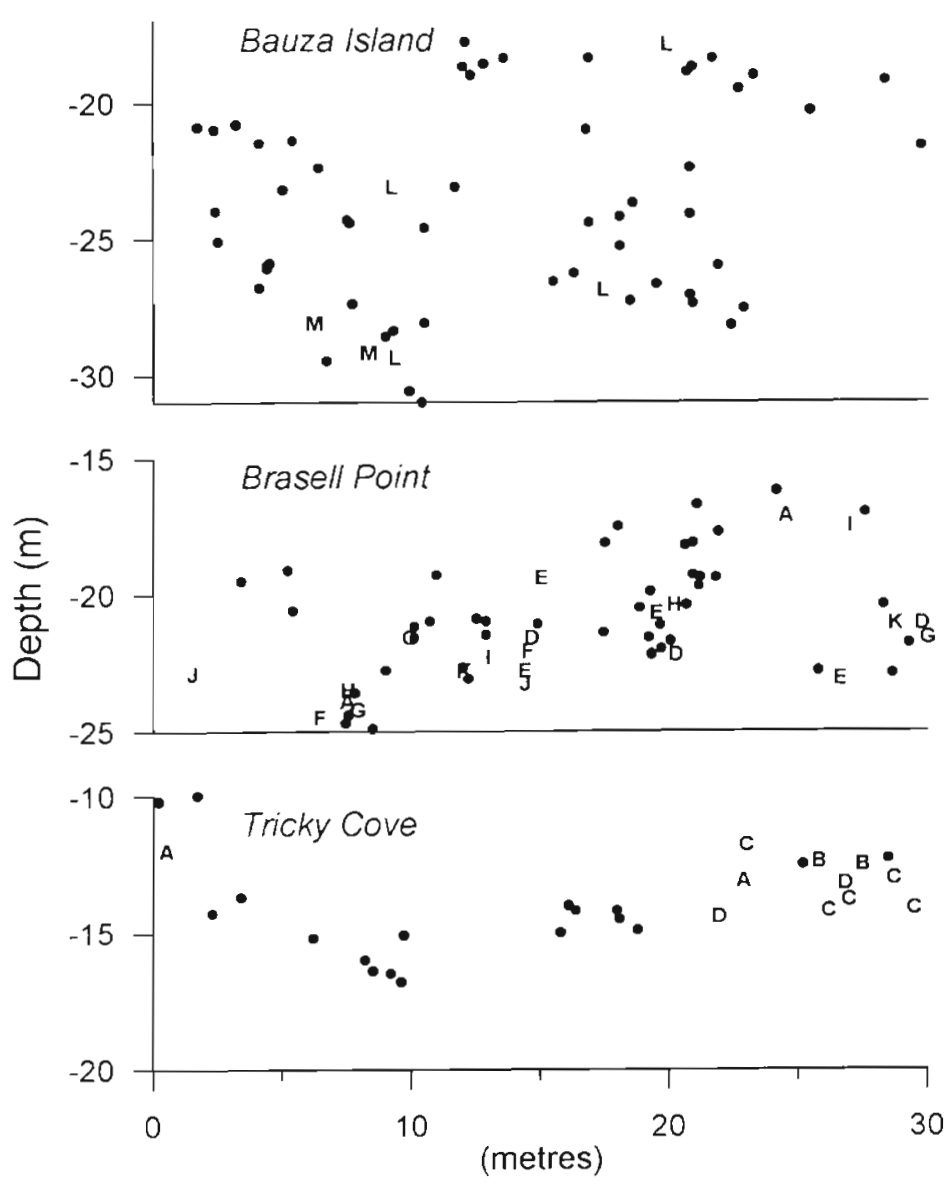

Fig. 2. Antipathes fiordensis. Plots showing the the location of all mapped colonies at each site. (•) Location of colonies with unique 10locus genotypes; letters denote the position of the 13 clonal genotypes (i.e. colonies with the same letter have the same 10-locus genotype)

\section{Genetic structure}

Genetic analysis indicated significant population structuring occurred at each of the 3 sites. Differences in allele frequencies were apparent among the sites; for example at the locus $H k-2$, allele $A$ was twice as common at Bauza Island than at the other 2 sites (Table 1). Similar differences in allele frequencies were apparent at the loci Est-2 and $H k-1$ (Table 1). These differences are consistent with results from similar comparisons of black coral populations in 13 fiords from throughout Fiordland which have shown significant genetic differentiation between sites separated by 10 to $15 \mathrm{~km}$ (Miller 1997, Miller \& Grange in press).

Tests for the conformance of gene frequencies to those expected under Hardy-Weinberg equilibrium indicated departures from random mating at all 3 sites. At least 1 locus, and up to 6 loci at Bauza Island, displayed significant departures from equilibrium (Table 2). Heterozygote excesses were found at Gpi at all 3 sites, and heterozygote deficits were apparent at $\mathrm{La}-2$ at both Brasell Point and Bauza Island and at $H k-2, L a-1$, Est-1 and $I d h$ at Bauza Island (Table 2). Only 4 of the 10 loci matched equilibrium at all 3 sites.
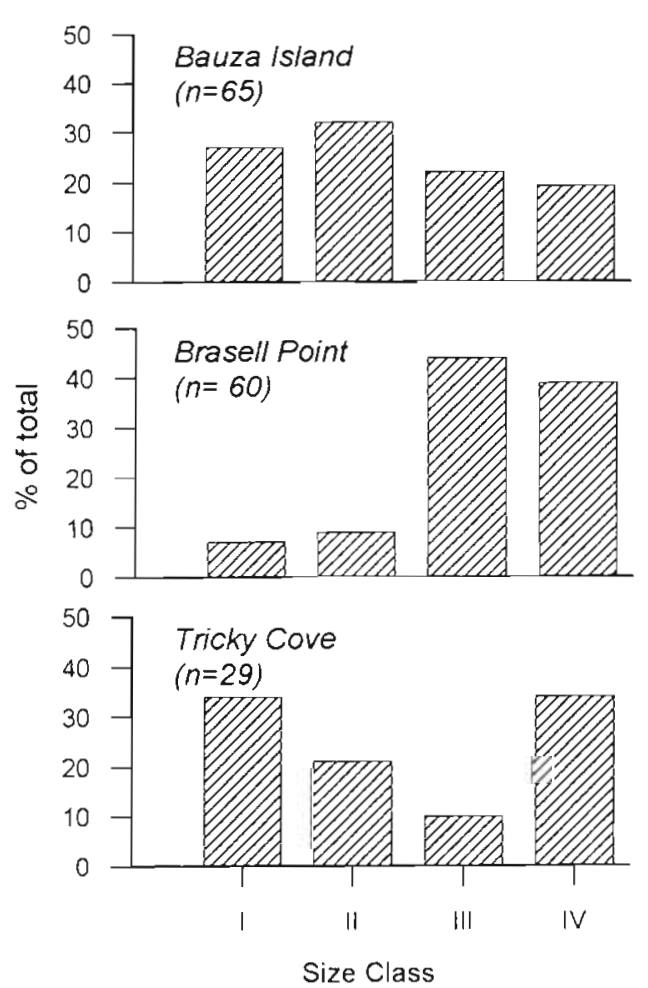

Fig. 3. Antipathes fiordensis. Size frequency distributions from the 3 study sites. Size classes are based on colony height (I: $<150 \mathrm{~mm}_{i}$ II: $150-300 \mathrm{~mm}$; III: $300-500 \mathrm{~mm}$; IV: $>500 \mathrm{~mm}$ 
Table 1. Antipathes fiordensis. Allelic frequencies and genotypic diversity from populations at 3 sites in Doubtful Sound. $N_{c}$ : number of clonal genotypes; $N_{1}$ : total number of individuals (colonies). Genotypic diversity ratio significantly less than $1(p<0.05)$

\begin{tabular}{|c|c|c|c|c|}
\hline \multicolumn{2}{|c|}{ Locus/allele } & \multirow{2}{*}{$\begin{array}{c}\text { Bauza Island } \\
0.946\end{array}$} & \multirow{2}{*}{$\begin{array}{c}\text { Brasell Point } \\
\qquad 1.000\end{array}$} & \multirow{2}{*}{$\begin{array}{c}\text { Tricky Cove } \\
1.000\end{array}$} \\
\hline Est-1 & A & & & \\
\hline & $\mathrm{B}$ & 0.054 & - & - \\
\hline \multirow[t]{3}{*}{ Est-2 } & A & 0.063 & 0.173 & 0.136 \\
\hline & $\mathrm{B}$ & 0.893 & 0.683 & 0.818 \\
\hline & C & 0.045 & 0.144 & 0.045 \\
\hline \multirow[t]{3}{*}{$I d h$} & A & 0.893 & 1.000 & 1.000 \\
\hline & B & 0.089 & - & - \\
\hline & C & 0.018 & - & - \\
\hline \multirow[t]{4}{*}{$P g m$} & A & 0.080 & 0.010 & 0.045 \\
\hline & B & 0.482 & 0.481 & 0.523 \\
\hline & $\mathrm{C}$ & 0.438 & 0.471 & 0.432 \\
\hline & $\mathrm{D}$ & - & 0.038 & - \\
\hline \multirow[t]{2}{*}{$G p i$} & A & 0.482 & 0.490 & 0.455 \\
\hline & $\mathrm{B}$ & 0.518 & 0.510 & 0.545 \\
\hline \multirow[t]{2}{*}{$M d h$} & A & 0.196 & 0.221 & 0.136 \\
\hline & B & 0.804 & 0.779 & 0.864 \\
\hline \multirow[t]{4}{*}{$H k-1$} & A & 0.009 & - & - \\
\hline & B & 0.436 & 0.286 & 0.409 \\
\hline & C & 0.245 & 0.057 & 0.136 \\
\hline & $\mathrm{D}$ & 0.309 & 0.657 & 0.455 \\
\hline \multirow[t]{4}{*}{ HK-2 } & A & 0.446 & 0.240 & 0.205 \\
\hline & $B$ & 0.071 & 0.020 & 0.045 \\
\hline & $\mathrm{C}$ & 0.464 & 0.740 & 0.750 \\
\hline & $\mathrm{D}$ & 0.018 & - & - \\
\hline \multirow[t]{3}{*}{$L a-1$} & A & 0.054 & - & - \\
\hline & B & 0.866 & 1.000 & 0.977 \\
\hline & $C$ & 0.080 & - & 0.023 \\
\hline \multirow[t]{3}{*}{$L a-2$} & A & 0.009 & - & - \\
\hline & B & 0.866 & 0.922 & 1.000 \\
\hline & C & 0.125 & 0.078 & - \\
\hline \multicolumn{2}{|l|}{$\begin{array}{l}N_{\mathrm{c}} \\
N\end{array}$} & 56 & 52 & 22 \\
\hline$N_{1}$ & & 65 & 60 & 29 \\
\hline \multicolumn{2}{|l|}{$G_{O}: G_{E}$} & 0.919 & 0.885 & $0.728^{\circ}$ \\
\hline
\end{tabular}

The ratio of observed to expected genotypic diversity $\left(G_{\mathrm{O}}: G_{\mathrm{E}}\right)$ was less than 1 (the value expected in a randomly mating population) at all 3 sites. Genotypic diversity is sensitive to any form of single or multilocus disequilibrium and values less than 1 may simply reflect departures from random mating as discussed above. However, $G_{O}$ was significantly less than $G_{E}$ at Tricky Cove ( $p<0.05$, Table 1$)$, indicating that asexual reproduction is likely to play an important role in recruitment at this site. Some clonal genotypes were found both at Brasell Point and Tricky Cove (clones A and $D_{i}$ Fig. 2), although the remaining 11 clonal genotypes were unique to their respective sites (Fig. 2). It should be noted that some of these clones have been recorded at other sites within Doubtful Sound and in some cases, in other fiords (see Miller 1997, Miller \&
Table 2. Antipathes fiordensis. Wright's fixation index (f) for populations from 3 sites in Doubtful Sound. Negative values of $f$ indicate heterozygote excesses and positive values indicate heterozygote deficits. Significant departures from Hardy-Weinberg equilibrium are noted as: $p<0.05, \cdots p<$ $0.01, \cdots p<0.001$. ' - represents loci that were monomorphic at each site

\begin{tabular}{|lccc|}
\hline Locus & Bauza Island & Brasell Point & Tricky Cove \\
\hline Est-1 & $1.000^{\circ}$ & - & - \\
Est-2 & 0.274 & 0.244 & -0.173 \\
Idh & $1.000^{\circ}$ & - & - \\
Pgm & -0.066 & 0.013 & 0.071 \\
Gpi & $-0.860^{\circ} \cdots$ & $-0.962^{\circ}$ & $-0.833 \cdots$ \\
Mdh & 0.095 & 0.051 & -0.158 \\
Hk-1 & 0.054 & -0.182 & -0.197 \\
Hk-2 & $0.415^{\circ}$ & 0.087 & 0.423 \\
La-1 & $0.629^{\circ}$ & - & -0.023 \\
La-2 & $0.924^{\circ}$ & $1.000^{\circ}$ & - \\
\hline
\end{tabular}

Grange in press). While it is unusual for clones to be widely distributed, the probability of these clonal genotypes occurring more than once in the sample has been calculated to be very low (Miller 1997). Consequently it is assumed that the putative clones identified on the basis of 10-locus genotypes are the product of asexual reproduction.

No significant genotypic linkage disequilibrium was detected at either Tricky Cove or Brasell Point. At Bauza Island, non-random genotypic associations were detected between Gpi and Est-2 and between $\mathrm{Hk}-1$ and $H k-2$, although these did not remain significant after the correction of $p$-values for multiple simultaneous tests.

\section{Spatial pattern}

Spatial autocorrelation analyses indicated that the distribution of genotypes differed among the 3 sites. At Tricky Cove genotypes of colonies separated by $<5 \mathrm{~m}$ were more similar than colonies further apart. Significant autocorrelation was detected at 4 of the 6 loci analysed with most alleles showing the same pattern of positive correlation at small distance classes and negative correlation at larger distance classes (Fig, 4). At Brasell Point allele distribution was largely random over all distance classes with the exception of a significant positive correlation of $G p i(\mathrm{~A})$ and $H k-2(\mathrm{~A})$ at 0 to $5 \mathrm{~m}$, although the values of Moran's I were very low and may not be biologically meaningful (Fig. 4). Similarly, at Bauza Island most alleles had a random distribution with distance class with the exception of alleles $H k-2(\mathrm{~A})$ and $(\mathrm{C})$, which were positively correlated at small distances (up to $10 \mathrm{~m}$ ) but negatively correlated at larger distances (10 to $50 \mathrm{~m}$; Fig. 4). Interestingly, all 


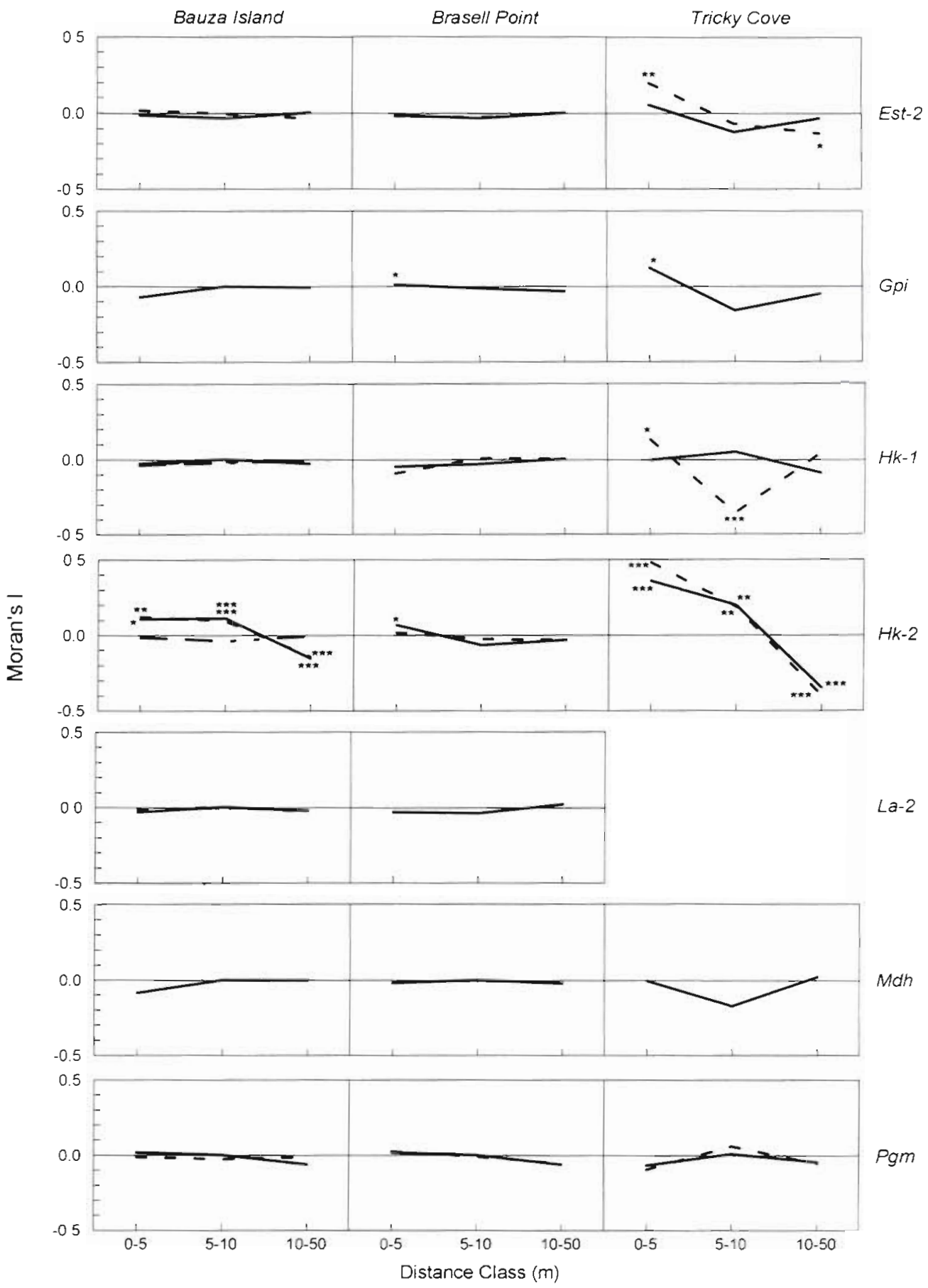

Fig. 4. Spatial autocorrelation correlograms of Moran's I plotted against distance class. Solid lines (-) represent alleles Est-2 (A), Pgm (B), Gpi (A), $M d h(\mathrm{~A}), H k-1$ (B), $H k-2$ (A) and $L a-2(B)$; dashed lines (- -) represent alleles Est-2 (B), Pgm (C). $H k-1$ (D), Hk-2 (C) and La-2 (C); short-long dashed lines (- -) represent alleles $H k-1$ (C) and $H k-2$ (B). Values of Moran's I significantly different to expected values are denoted by " $p<0.05$,

${ }^{* *} \mathrm{p}<0.01,{ }^{* * *} \mathrm{p}<0.001$

significant relationships indicated a positive correlation between close neighbours and $\mathrm{Hk}-2$ showed significant patterns at all 3 sites. Furthermore, estimates of patch size are small (approximately 5 to $10 \mathrm{~m}$, as determined from the point at which the correlogram first crosses the $x$-axis; Sokal \& Wartenberg 1983) and are similar at all 3 sites.

Results from multivariate analysis of association between genetic distance and Euclidean distance for black corals within each of the 3 sites revealed patterns similar to the single locus spatial autocorrelation analyses. At Tricky Cove, a small positive correlation between genotype and distance was detected ( $\mathrm{r}=0.2$ ) which was highly significant ( $p=0.007$ ). At Bauza Island and Brasell Point there was no significant correlation between Nei's $D$ and Euclidean distance $(\mathrm{r}=0.06, \mathrm{p}=0.127 ; \mathrm{r}=0.08, \mathrm{p}=$ 0.125 respectively) indicating a random distribution of multilocus genotypes throughout the mapped plots. 


\section{DISCUSSION AND CONCLUSIONS}

The genetic structure observed within populations of Antipathes fiordensis is consistent with restricted larval dispersal within the fiords of New Zealand. Previous studies of $A$. fiordensis have demonstrated that sexually produced larvae of $A$. fiordensis are unlikely to move distances of 10 to $15 \mathrm{~km}$ (Miller 1997, Miller \& Grange in press), and this result has been confirmed here. At distances less than 10 to $15 \mathrm{~km}$, prediction of dispersal distance is likely to be problematical. At Tricky Cove colonies in close proximity (i.e. separated by less tizan $5 \mathrm{~m}$ ) are more likely to be related than colonies which are further apart and this result is consistent for both univariate and multivariate spatial analyses. Therefore, in at least 1 area within Doubtful Sound, it is likely that larvae have settled and recruited very close to the parent colonies. At the other 2 sites (Bauza Island and Brasell Point) no association was found between genotype and distance, suggesting wider dispersal of gametes and/or larvae, at least over distances up to approximately $50 \mathrm{~m}$ (although see discussion of differential recruitment below). However, estimates of patch size are similar among the 3 sites $(<10 \mathrm{~m})$, consistent with the hypothesis of small-scale segregation of black coral populations within Doubtful Sound.

The spatial structure observed at Tricky Cove may be related to asexual reproduction which has been reported in Antipathes fiordensis (Miller \& Grange in press). Clones at Tricky Cove are more aggregated than the clones at the other 2 sites (Fig. 2), so it is possible that the significant spatial relationship observed at Tricky Cove is due to localised and/or aggregated recruitment of asexual larvae (see also Miller 1997). To test the influence of asexual recruitment on the spatial structure at Tricky Cove, the autocorrelation analysis was re-run using a weight matrix to exclude clone pairs. The correlograms from this analysis (not shown) revealed similar patterns to those found when all colony pairs were analysed. It is therefore unlikely that the spatial structure observed at Tricky Cove arose from aggregated asexual recruitment.

The different spatial patterns at each of the 3 study sites suggest that the scale of larval dispersal may be variable, even within a single fiord. These variations are likely to be associated both with physical and biological factors, e.g. water flow (Richards et al. 1995), gamete dispersal (Grosberg 1991) and post-settlement mortality (Grange in press).

The fiords are calm environments with weak currents (Stanton \& Pickard 1981). Water movement decreases rapidly from the mouth of the fiord, which is influenced by oceanic swells, to the head of the fiord, where flow is minimal. The decrease in larval dispersal distance between the Bauza Island site, located towards the mouth of Doubtful Sound, and the Tricky Cove site, located mid-fiord, may reflect the decrease in larval dispersal associated with reduced water movement. Unfortunately, the 'normal' flow regime at Brasell Point has been drastically altered in the last 30 yr by the Manapouri Power Station, which discharges an average of $350 \mathrm{~m}^{3}$ of water per second into the fiord via a tailrace tunnel located close to Brasell Point. This dramatic increase in water input may have influenced more recent larval dispersal at this site and confounded the direct interpretation of spatial structure according to water flow.

Micro-scale water flow is considerably reduced close to the rock walls of the fiords, and especially around black coral colonies (F. Smith \& K. Grange pers. comm.). These effects will reduce the dispersal both of gametes and larvae (e.g. Graham \& Sebens 1996) and contribute to the spatial association of genotypes as described here. In this study it was impossible to separate the respective roles of gamete and larval dispersal for gene flow (e.g. Grosberg 1991), although clearly gene flow by either means is limited in Antipathes fiordensis. Little is known about spawning in $A$. fiordensis, or how spawning behaviour influences the dispersal of gametes. Gene flow and the ultimate genetic make up of coral recruits is likely to be influenced by a variety of factors including fertilisation success as related to spawning synchrony (e.g. Babcock \& Mundy 1992, Oliver \& Babcock 1992), the timing of spawning relative to tidal flows and weather conditions (e.g. Willis \& Oliver 1990), variations in these factors over different years (e.g. Lasker et al. 1996), as well as dispersal of the larvae themselves.

Differences in recruitment history at the 3 sites may also be an important factor contributing to the variation in spatial patterns among sites. Recruitment rates of black corals are low and sporadic (Grange in press). Tricky Cove had high numbers of small colonies (size class 1; Fig. 3) relative to colonies in larger size classes, compared with the other 2 sites. It may be that the positive spatial correlation at Tricky Cove reflects a 'recent' recruitment event and that the positive correlation of genotypes with distance may be reduced over time, with subsequent high mortality of small colonies (Grange in press). Settlement of larvae close to parents may occur at all 3 sites but poor recruitment in recent years at Brasell Point (where recruitment combines the effects of settlement and post-settlement mortality) and relatively uniform rates of recruitment through time at Bauza Island (Fig. 3) may result in the spatial patterns observed at these sites (e.g. Peakall \& Beattie 1995).

This study has shown larval dispersal in Antipathes fiordensis is philopatric and as a result, population subdivision occurs at very small scales. The evolutionary 
consequences of restricted larval dispersal in marine invertebrates are likely to be varied (e.g. Burton 1986, Hedgecock 1986, Jackson 1986, Havenhand 1995) although in Antipathes fiordensis the adaptive significance of restricted larval dispersal remains unclear. Retaining larvae close to adults, in habitats suitable for survival, seems to be paradoxical as the fiords are thought to be a stable and uniform environment. However, fiord populations of $A$. fiordensis are geologically very recent (Pickrill et al. 1992). Restricted larval dispersal may therefore be an adaptation for the deep sea environments in which black corals usually live (e.g. isolated rock outcrops on the continental shelf) and may not be a specialised adaptation for the fiord conditions.

An important consequence of restricted gamete and larval dispersal is the increased potential for inbreeding. Heterozygote deficiencies in Antipathes fiordensis populations (Table 2; Miller 1997) suggest inbreeding may be occurring in Fiordland black corals. Philopatry as an adaptation for inbreeding has been suggested (Shields 1982, Jackson 1986), although for marine invertebrates it is thought that direct selection for inbreeding does not occur, but rather that it arises as a consequence of selection for other ecological factors (Knowlton \& Jackson 1993). There is some suggestion of differential selective pressures operating throughout the fiords. Significant heterozygote excesses at Gpi, in contrast to heterozygote deficits at all other loci (Table 2), may indicate selection operating at that locus although heterozygote excesses are apparent at other loci in some fiord populations of A. fiordensis; Miller 1997). Significant positive spatial autocorrelation of only one or 2 loci at Bauza Island and Brasell Point (Fig. 3) may also indicate differential selection operating within the fiords, which may ultimately influence the spatial association among genotypes at each site.

In conclusion, restricted dispersal of Antipathes fiordensis larvae has resulted in high population subdivision. This subdivision is apparent throughout Fiordland (Miller 1997) and the results from the present study indicate that larval dispersal in some areas will be restricted to as little as $5 \mathrm{~m}$ from the parent colonies. Clearly many ecological and evolutionary factors are likely to contribute to larval dispersal and the spatial associations of genotypes. However population subdivision, originating from limited gene flow, inbreeding and localised selection, is anomalous in Fiordland, a habitat which has previously been perceived as a continuous and homogeneous environment.

The black coral populations in New Zealand's fiords are the only shallow water population of antipatharians in the world. The corals are completely protected both under local and international regulations, but their habitat is not. The total area of shallow water habitat in the fiords is less than $50 \mathrm{~km}^{2}$ (Grange 1985). The limited larval dispersal and small patch sizes described for Antipathes fiordensis in this study, in combination with factors such as low recruitment and growth rates (Grange in press), emphasise the fragility of the black coral populations and highlight the impacts that even localised habitat destruction, either natural or anthropogenic, may have on the standing crop and genetic diversity of black corals. These factors emphasise the importance of a management strategy to protect the marine habitats within New Zealand's fiords, to ensure the conservation of these unique and fragile coral communities.

Acknowledgements. Special thanks to the devoted 'bag ladies' who spent many hours underwater helping me to collect samples for this study: Dick Singleton, Ken Grange and Franz Smith. I also thank Craig Mundy for guiding me through the pleasures of spatial autocorrelation, and David Ayre, Jonathan Gardner, Ken Grange and Russ Babcock, who provided many useful comments on early drafts of this paper. The laboratory analysis of genetic samples was carried out by the author at Victoria University of Wellington, under an agreement between NIWA and VUW link.

\section{LITERATURE CITED}

Ayre DJ, Dufty S (1994) Evidence of restricted gene flow in the viviparous coral Seriatopora hystrix on Australia's Great Barrier Reef. Evolution 48:1183-1201

Babcock RC, Mundy CN (1992) Reproductive biology, spawning and field fertilisation rates of Acanthaster planci. Aust J Mar Freshwat Res 43:525-534

Bertness MD, Gaines SD (1993) Larval dispersal and local adaptation in acorn barnacles. Evolution 47:316-320

Burton RS (1986) Evolutionary consequences of restricted gene flow among natural populations of the copepod, Tigriopus californicus. Bull Mar Sci 39:526-535

Cliff AD, Ord JK (1973) Spatial autocorrelation. Pion, London

Dewey SE, Heywood JS (1988) Spatial genetic structure in a population of Psychotria nervosa 1. Distribution of genotypes. Evolution 42:834-838

Elston RC, Forthofer $R$ (1977) Testing for Hardy-Weinberg equilibrium in small samples. Brometrics 33:536-542

Epperson BK, Allard RW (1989) Spatial autocorrelation analysis of the distribution of genotypes within populations of lodgepole pine. Genetics 121:369-377

Fortin MJ, Gurevitch J (1993) Mantel tests: spatial structure in field experiments. In: Scheiner SM, Gurevitch J (eds) Design and analysis of ecological experiments. Chapman \& Hall, New York, p 342-359

Gerodette T (1981) The distribution of the solitary coral Balanophylia elegans by demersal planular larvae. Ecology 62:611-619

Graham KR, Sebens KP (1996) The distribution of marine invertebrate larvae near vertical surfaces in the rocky subtidal zone. Ecology 77:933-949

Grange KR (1985) Distribution, standing crop, population structure, and growth rates of black coral in the southern fiords of New Zealand. NZ J Mar Freshwat Res 19:467-475

Grange KR (1990) Antipathes fiordensis, a new species of black coral (Coelenterata:Antipatharia) from New Zealand. NZ J Zool 17:279-282 
Grange KR (in press) Demography of black coral populations in Doubtful Sound, New Zealand: results from a sevenyear experiment. Proceedings of the 6th International Conference on Coelenterate Biology. National Museum of Natural History, Leiden

Grange KR, Goldberg WM (1993) Chronology of black coral growth bands: 300 years of environmental history? Proc 2nd Int Temp Reef Symp, p 169-174

Grange KR, Singleton RJ (1988) Population structure of black coral, Antipathes aperta, in the southern fiords of New Zealand. NZ J Zool 15:481-489

Grange KR, Singleton RJ, Richardson JR, Hill PJ, Main WDeL (1981) Shallow rock wall biological associations of some southern fiords of New Zealand. NZ J Zool 8:209-227

Grosberg RK (1991) Sperm mediated gene flow and the genetic structure of a population of the colonial ascidian Botryllus schlosseri. Evolution 45:130-142

Havenhand JN (1995) Evolutionary ecology of larval types. In: McEdward L (ed) Ecology of marine invertebrate larvae. CRC Press, Boca Raton, FL, p 79-122

Hedgecock D (1986) Is gene flow from pelagic larval dispersal important in the adaptation and evolution of marine invertebrates. Bull Mar Sci 39:550-564

Hellberg ME (1994) Relationships between inferred levels of gene flow and geographic distance in a philopatric coral, Balanophyllia elegans. Evolution 48:1829-1854

Hellberg ME (1995) Stepping-stone gene flow in the solitary coral Balanophyllia elegans: equilibrium and non-equilibrium at different spatial scales. Mar Biol 123:573-581

Heywood JS (1991) Spatial analysis of genetic variation in plant populations. Ann Rev Ecol Syst 22:335-355

Jackson JBC (1986) Modes of dispersal of clonal benthic invertebrates: consequences for species' distributions and genetic structure of local populations. Bull Mar Sci 39: 588-606

Keough MJ, Chernoff H (1987) Dispersal and population variation in the bryozoan Bugula nertina. Ecology $68: 199-210$

Knowlton N, Jackson JBC (1993) Inbreeding and outbreeding in marine invertebrates. In: Thornhill NW (ed) The natural history of inbreeding and outbreeding Theoretical and empirical perspectives. University of Chicago Press, Chicago, p 200-249

Lasker HR, Brazeau DA, Calderon J, Coffroth MA, Coma R, Kim $\mathrm{K}(1996)$ In situ rates of fertilisation among broadcast spawning gorgonian corals. Biol Bull (Woods Hole) 190:45-55

McFadden CS, Aydin KY (1996) Spatial autocorrelation analysis of small-scale genetic structure in a clonal soft coral with limited larval dispersal. Mar Biol 126:215-224

Miller KJ (1996) Piecing together the reproductive habits of New Zealand's endemic black corals. Water Atmos 4: 18-19

Miller KJ (1997) Genetic structure of black coral populations in New Zealand's fiords. Mar Ecol Prog Ser 161:123-132

Miller KJ, Grange KR (in press) Population genetic studies of the antipatharian black coral Antipathes fiordensis from Doubtful and Nancy Sounds, Fiordland, New Zealand Proceedings of the 6th International Conference on Coelenterate Biology. National Museum of Natural History, Leiden

Miller RG (1966) Simultaneous statistical inference. McGrawHill, New York

Editorial responsibility: Otto Kinne (Editor), Oldendorf/Luhe, Germany
Mitton JB (1993) Theory and data pertinent to the relationship between heterozygosity and fitness. In: Thornhill NW (ed) The natural history of inbreeding and outbreeding. Theoretical and empirical perspectives. University of Chicago Press, Chicago, p 17-41

Oliver J, Babcock R (1992) Aspects of the fertilisation ecology of broadcast spawning corals: sperm dilution effects and in situ measurements of fertilisation. Biol Bull (Woods Hole) 183:409-417

Olsen RR (1985) The consequences of short-distance larval dispersal in a sessile marine invertebrate. Ecology 66 : 30-39

Parker NR (1995) Reproductive biology of black coral Antipathes fiordensis in Doubtful Sound, Fiordland. MSc thesis, University of Otago, Dunedin

Pickrill RA, Fenner JM, McGlone MS (1992) Late Quaternary evolution of a fiord environment in Preservation Inlet, New Zealand. Quat Res 38:331-346

Peakall R, Beattie AJ (1995) Does ant dispersal of seeds in Sclerolaena diacantha (Chenopodiaceae) generate local spatial genetic structure? Heredity 75:351-361

Raymond M, Rousset F (1994) Genepop, version 1.2: a population genetics software for exact tests and ecumenicism. Institut des Sciences de l'Evolution, Université de Montpellier, France

Richards SA, Possingham HP, Noye BJ (1995) Larval dispersion along a straight coast with tidal currents: complex distribution patterns from a simple model. Mar Ecol Prog Ser 122:59-71

Scheltema RS (1986) On dispersal and planktonic larvae of benthic invertebrates; an eclectic overview and summary of problems. Bull Mar Sci 39:290-322

Sebens KP (1983) The larval and juvenile ecology of the temperate octocoral Alcyonium siderium Verril. 1. Substratum selection by benthic larvae. J Exp Mar Biol Ecol 70:1-17

Shields WM (1982) Philopatry, inbreeding and the evolution of sex. State University of New York Press, Albany

Sokal RR, Oden NL (1978a) Spatial autocorrelation in biology 1. Methodology. Biol J Linn Soc 10:199-228

Sokal RR, Oden NL (1978b) Spatial autocorrelation in biology 2. Some biological implications and four applications of evolutionary and ecological interest. Biol J Linn Soc 10 $229-249$

Sokal RR, Wartenberg DE (1983) A test of spatial autocorrelation analysis using an isolation-by-distance model. Genetics 105:219-237

Stanton BR, Pickard GL (1981) Physical oceanography of the New Zealand fiords. New Zealand Oceanographic Institute Memoir 88, Wellington

Stoddart JA (1988) Historecognition and fine-scale spatial genetic structure in sessile benthic invertebrates. In. Grosberg RK, Hedgecock D, Nelson K (eds) Invertebrate historecognition. Plenum Publishing Corporation, New York

Stoddart JA, Taylor JF (1988) Genotypic diversity: estimation and prediction in samples. Genetics 118:705-711

Suggate RP, Stevens GR, TePunga MT (eds) (1978) The geology of New Zealand. Government Printer, Wellington

Willis BL, Oliver JK (1990) Direct tracking of coral larvae implications for dispersal studies of planktonic larvae in topographically complex environments. Ophelia 32 145-162

Submitted: May 20, 1997; Accepted: December 23, 1997

Proofs received from author(s): February 16, 1998 